\title{
HUBUNGAN STATUS GIZI DENGAN TEKANAN DARAH PADA SISWA SEKOLAH MENENGAH PERTAMA NEGERI 1 KOTA BITUNG
}

\author{
${ }^{1}$ Jenifer Andalangi \\ ${ }^{2}$ Sarah M. Warouw \\ ${ }^{2}$ Adrian Umboh
}

\author{
${ }^{1}$ Kandidat Skripsi Fakultas Kedokteran Universitas Sam Ratulangi Manado \\ ${ }^{2}$ Bagian Ilmu Kesehatan Anak Fakultas kedokteran Universitas Sam Ratulangi Manado \\ Email: jeniferandalangi@yahoo.com
}

\begin{abstract}
According to Riskesdas in 2010, the prevalences of nutritional status based on BMI at age group $13-15$ in North Sulawesi were $0.7 \%$ very skinny; $5.3 \%$ thin; $90,5 \%$ normal; and $3.4 \%$ obese. In Indonesia, the incidences of hypertension in adolescents varies from $3.11 \%$ to $4.6 \%$. BMI has a strong relationship with blood pressure; BMI $\geq 95$ th percentile was strongly associated with increased blood pressure $\geq 90$ th percentile. This study aimed to determine the relationship of the nutritional status and blood pressure. The study was conducted in SMPN 1 Bitung. This was an analytic obsevational study with a cross-sectional design. Samples were 105 students aged 11-14 years, obtained by using simple random sampling. The nutritional status was defined as independent variables and the blood pressure as the dependent variable. Data were analyzed by using a chi-square test. The results showed that the nutritional status of students were underweight $10.5 \%$, normal $71.4 \%$, overweight $13.3 \%$, and obese $4.8 \%$. The normal blood pressure were found in 89.5\%; high normal blood pressure 8.6\%; and hypertension $1.9 \%$. The chi-square test results showed a significant relationship between the nutritional status and the blood pressure $(P=0.001)$. Conclusion: There was a significant relationship between the nutritional status and the blood pressure among the junior high school students in Bitung.
\end{abstract}

Keywords: blood pressure; nutritional status.

\begin{abstract}
Abstrak: Berdasarkan laporan Riskesdas tahun 2010, prevalensi status gizi berdasarkan IMT pada kelompok usia 13-15 tahun di Provinsi Sulawesi Utara menunjukkan angka 0,7\% sangat kurus, 5,3\% kurus, 90,5\% normal, dan 3,4\% gemuk. Di Indonesia, angka kejadian hipertensi pada remaja bervariasi dari $3,11 \%$ sampai $4,6 \%$. IMT mempunyai hubungan yang kuat dengan tekanan darah, yaitu IMT $\geq$ persentil 95 berhubungan kuat dengan peningkatan tekanan darah $\geq$ persentil 90. Penelitian ini bertujuan untuk mengetahui hubungan status gizi dan tekanan darah. Penelitian dilakukan di SMP N 1 Bitung. Penelitian ini menggunakan metode survei analitik observasional dengan desain potong lintang, dengan jumlah sampel 105 siswa berusia 11-14 tahun, yang diambil dengan simple random sampling. Status gizi ditetapkan sebagai variabel independen dan tekanan darah sebagai variabel dependen. Uji statistik yang digunakan ialah chi-square. Untuk status gizi di dapat underweight 10,5\%, normal $71,4 \%$, overweight $13,3 \%$, dan obes $4,8 \%$. Untuk tekanan darah didapatkan tekanan darah normal 89,5\%, normal tinggi 8,6\%, dan hipertensi 1,9\%. Hasil uji chi-square menyatakan adanya hubungan bermakna antara status gizi dan tekanan darah $(P=0,001)$. Simpulan: Terdapat hubungan bermakna antara status gizi dan tekanan darah.
\end{abstract}

Kata kunci: status gizi, tekanan darah. 
Remaja merupakan kelompok peralihan dari anak-anak ke dewasa dan rentan terhadap perubahan-perubahan di lingkungan sekitarnya, termasuk pengaruh konsumsi makanan. Kebiasaan remaja terhadap makanan sangat beragam seperti bersifat acuh terhadap makanan, lupa waktu makan karena padatnya aktivitas, makan berlebih, mengikuti tren makan fast food dan sebagainya, tanpa memperhatikan kecukupan gizi yang mereka butuhkan. ${ }^{1}$ Laporan Riset Kesehatan Dasar (RISKESDAS) tahun 2010 memperlihatkan bawha prevalensi status gizi berdasarkan IMT pada kelompok usia 13-15 tahun di Provinsi Sulawesi Utara menunjukkan angka 0,7\% sangat kurus, 5,3\% kurus, 90,5\% normal, dan $3,4 \%$ gemuk. $^{2}$

Obesitas merupakan keadaan patologis dimana terjadi penimbunan lemak berlebihan daripada yang diperlukan untuk mempertahankan fungsi tubuh. Dampak buruk obesitas terhadap kesehatan sangat berhubungan dengan berbagai macam penyakit serius seperti tekanan darah tinggi, jantung, diabetes mellitus, dan penyakit saluran napas. ${ }^{3}$ Prevalensi obesitas anak usia sekolah (6-14 tahun) di Indonesia 9,5\% pada laki-laki dan $6,4 \%$ pada perempuan. ${ }^{4}$

Hipertensi merupakan kelainan kardiovaskuler yang banyak dijumpai dalam masyarakat. Prevalensi hipertensi dalam masyarakat Indonesia masih cukup tinggi meskipun tidak setinggi di negara maju yaitu sekitar 10\%. Komplikasi hipertensi dapat mengenai organ target jantung, otak (serebrovaskular), mata, dan ginjal. Penyebab hipertensi pada remaja (usia 13-18 tahun) yang paling sering ialah hipertensi esensial (80\%), diikuti penyakit ginjal. Di Indonesia angka kejadian hipertensi pada remaja bervariasi dari 3,11\% sampai 4,6\%. ${ }^{5}$ IMT mempunyai hubungan yang kuat dengan tekanan darah. IMT $\geq$ persentil 95 berhubungan kuat dengan peningkatan tekanan darah $\geq$ persentil 90. Pada remaja laki-laki dan perempuan dengan IMT $\geq$ persentil 90 mempunyai tekanan darah sistolik tinggi sebesar $35,7 \%$ dan $14 \%$, dan tekanan darah diastolik tinggi sebesar $24,7 \%$ dan $15,9 \%{ }^{4}$

\section{METODE PENELITIAN}

Jenis penelitian ini ialah survei analitik observasional dengan menggunakan desain potong lintang. Jumlah sampel sebanyak 105 siswa, diambil dengan menggunakan rumus Normogram Harry King. Sampel berusia 11-14 tahun diperoleh melalui simple random sampling. Status gizi ditetapkan sebagai variabel independen dan tekanan darah sebagai variabel dependen. Uji statistik yang digunakan ialah chi-square test dengan derajat kemaknaan $P=<0,05$.

\section{HASIL PENELITIAN DAN BAHASAN}

Dari data responden semua siswa Sekolah Menengah Pertama, yang diambil sebagai sampel berjumlah 105 siswa (Tabel 1). Terdapat 13 siswa usia 11 tahun (12,4\%), 34 siswa usia 12 tahun $(32,4 \%)$, 37 siswa usia 13 tahun (35,2\%), dan 21 siswa usia 14 tahun (20,0 \%). Berdasarkan jenis kelamin didapatkan 33 siswa laki-laki (31,4\%) dan 72 siswa perempuan (68,6\%). Juga didapatkan 94 siswa dengan tekanan darah normal (89,5\%), 9 siswa dengan tekanan darah normal tinggi (8,6\%), dan 2 siswa dengan hipertensi (1,9\%). Untuk status gizi di dapat 11 siswa underweight (10,5\%), 75 siswa status gizi normal (71,4\%), 14 siswa overweight (13,3\%), dan 5 siswa obes $(4,8 \%)$.

Distribusi status gizi berdasarkan jenis kelamin (Tabel 2) memperlihatkan jenis kelamin laki-laki dengan underweight 4 siswa (12,1\%), normal 22 siswa (66,7\%), overweight 4 siswa (12,1\%), dan obes 3 siswa $(9,1 \%)$. Untuk jenis kelamin perempuan dengan underweight didapatkan 6 siswa (8,3\%), status gizi normal 53 siswa (73,6\%), overweight 11 siswa (15,3\%), dan obes 2 siswa (2,8\%). Data di atas memperlihatkan bahwa siswa obese lebih banyak pada jenis kelamin laki-laki; hal ini serupa dengan penelitian lainnya di Medan (2010), yang menyatakan bahwa dari sampel sebanyak 400 siswa berusia 6-12 tahun, yang terbanyak mengalami obesitas ialah jenis kelamin laki-laki. ${ }^{6}$

Penelitian di Yogyakarta (2003) juga 
Tabel 1. Profil responden dari siswa SMP N 1 Bitung

\begin{tabular}{lllcc}
\hline \multirow{2}{*}{ No } & & \multirow{2}{*}{ Klasifikasi } & \multicolumn{2}{c}{ Jumlah } \\
\cline { 3 - 5 } & & & $\mathrm{N}$ & $\%$ \\
\hline 1. & Jenis & Laki-laki & 33 & 31,4 \\
& Kelamin & Perempuan & 72 & 68,6 \\
2. & Umur & 11 & 13 & 12,4 \\
& & 12 & 34 & 32,4 \\
& & 13 & 37 & 35,2 \\
& & 14 & 21 & 20,0 \\
3. & Status Gizi & Underweight & 11 & 10,5 \\
& & Normal & 75 & 71,4 \\
& & Overweight & 14 & 13,3 \\
& & Obese & 5 & 4,8 \\
4. & Tekanan & Normal & 94 & 89,5 \\
& Darah & Normal & 9 & 8,6 \\
& & Tinggi & & \\
& & Hipertensi & 2 & 1,9 \\
& & & 105 & 100 \\
\hline
\end{tabular}

memperlihatkan prevalensi obesitas pada laki-laki (6,6\%) lebih banyak dibanding perempuan $(3,5 \%))^{7}$ Penelitian lainnya yaitu di Manado (2004) juga menyebutkan bahwa jumlah anak laki-laki yang obes (40 siswa, 55,5\%) lebih banyak dari siswa perempuan (32 siswa, $44,5 \%)^{8}$

Dari data distribusi tekanan darah berdasarkan jenis kelamin (Tabel 3) di dapatkan siswa laki-laki dengan tekanan darah normal sebanyak 31 (94\%), normal tinggi 1 (3\%), dan hipertensi 1 siswa (3\%). Untuk siswa perempuan dengan tekanan darah normal didapat 63 siswa $(87,5 \%)$, normal tinggi 8 (11,1\%), dan hipertensi 1 siswa $(1,4 \%)$. Hasil penelitian ini berbeda dengan hasil penelitian oleh Eva dan Apoina di Kaur Selatan (2012) dengan prevalensi hipertensi terbanyak pada anak laki-laki yaitu $16,7 \%$, sedangkan pada anak perempuan $12,5 \%{ }^{4}$

Tabel 4 memperlihatkan hasil pengujian hipotesis antara status gizi dan tekanan darah yang didapat. Untuk yang underweight, tekanan darah normal pada 11 siswa, dan tidak ditemukan yang bertekanan darah normal tinggi maupun hipertensi. Untuk yang berstatus gizi normal, tekanan darah normal didapatkan pada 70 siswa, normal tinggi 5 siswa, sedangkan yang hipertensi tidak ada.
Untuk

Tabel 2. Distribusi status gizi berdasarkan jenis kelamin

\begin{tabular}{lcccc}
\hline \multirow{2}{*}{ Status Gizi } & \multicolumn{4}{c}{ Jenis Kelamin } \\
& \multicolumn{2}{c}{ Laki-laki } & \multicolumn{2}{c}{ Perempuan } \\
\cline { 2 - 5 } & $\mathrm{n}$ & $\%$ & $\mathrm{n}$ & $\%$ \\
\hline Underweight & 4 & 12,1 & 6 & 8,3 \\
Normal & 22 & 66,7 & 53 & 73,6 \\
Overweight & 4 & 12,1 & 11 & 15,3 \\
Obese & 3 & 9,1 & 2 & 2,8 \\
Jumlah & 33 & 100 & 72 & 100 \\
\hline
\end{tabular}

Tabel 3. Distribusi tekanan darah berdasarkan jenis kelamin

\begin{tabular}{lcccc}
\hline \multirow{2}{*}{\begin{tabular}{c}
\multirow{2}{*}{ Tekanan } \\
Darah
\end{tabular}} & \multicolumn{4}{c}{ Jenis Kelamin } \\
& \multicolumn{2}{c}{ Laki-laki } & \multicolumn{2}{c}{ Perempuan } \\
\cline { 2 - 5 } & $\mathrm{n}$ & $\%$ & $\mathrm{n}$ & $\%$ \\
\hline Normal & 31 & 94 & 63 & 87,5 \\
Normal Tinggi & 1 & 3 & 8 & 11,1 \\
Hipertensi & 1 & 3 & 1 & 1,4 \\
Jumlah & 33 & 100 & 72 & 100 \\
\hline
\end{tabular}

yang overweight tekanan darah normal didapatkan pada 11 siswa, normal tinggi 2 siswa, dan hipertensi 1 siswa. Untuk yang obes, tekanan darah normal didapatkan pada 2 siswa, normal tinggi 2 siswa, dan yang hipertensi 1 siswa. Hasil uji $X^{2}$ menyatakan terdapat hubungan bermakna antara status gizi dan tekanan darah $(P=$ 0,001).

Adanya hubungan antara status gizi (dalam hal ini obesitas) dan tekanan darah (tekanan darah tinggi/hipertensi) ditemukan oleh Verma et al. ${ }^{9}$ yang menelilti siswa sekolah berusia 5-15 tahun di kota Punjab, India. Banyak penelitian epidemiologi telah menunjukkan terjadinya peningkatan progresif peningkatan tekanan darah atau hipertensi seiring dengan meningkatnya kejadian obesitas. Pada obesitas terjadi abnormalitas pada mekanisme kontrol tekanan arterial yang dapat meningkatkan tekanan darah, serta ekskresi natrium dan air melalui tekanan natriuresis dan dieresis. Selama ekskresi natrium dan air masih melebihi intake, terjadi peningkatan reabsorpsi pada tubular ginjal sehingga terjadi penurunan volum cairan ekstrasel 
dan cardiac output sampai tekanan darah

Tabel 4. Hubungan status gizi dengan tekanan darah

\begin{tabular}{|c|c|c|c|c|c|}
\hline \multirow[b]{2}{*}{ Status Gizi } & \multicolumn{3}{|c|}{ Tekanan Darah } & \multirow[b]{2}{*}{ Total } & \multirow[b]{2}{*}{$\boldsymbol{P}$} \\
\hline & Normal & $\begin{array}{c}\text { Normal } \\
\text { Tinggi }\end{array}$ & Hipertensi & & \\
\hline Underweight & 11 & 0 & 0 & 11 & \\
\hline Normal & 70 & 5 & 0 & 75 & 0,001 \\
\hline Overweight & 11 & 2 & 1 & 14 & \\
\hline Obese & 2 & 2 & 1 & 5 & \\
\hline
\end{tabular}

Uji statistik $=\mathrm{x}^{2}=\mathrm{p}=0,001$

kembali normal. Sebaliknya, bila tekanan darah menurun, ginjal akan menahan garam dan air sampai tekanan arterial kembali normal. Tekanan natriuresis merupakan kunci utama feedback system yang menstabilkan tekanan darah dan volum cairan tubuh. Selain itu, beberapa mekanisme lain juga dapat menjelaskan hipertensi pada obesitas antara lain aktivasi sympathetic nervous system (SNS), renninangiotensin system (RAS), glukokortikoid, jaringan lemak, perubahan struktur ginjal, resistensi insulin, hiperleptinemia, dan vascular endothelial dysfunction. ${ }^{4}$ Adanya kaitan antara obesitas dan tekanan darah ini juga dikemukakan oleh Sorof et al. ${ }^{10}$, dimana terjadi peningkatan tekanan darah pada anak dengan berat badan lebih.

\section{SIMPULAN}

Berdasarkan hasil penelitian dapat disimpulkan bahwa terdapat hubungan bermakna antara status gizi dan tekanan darah, yaitu semakin besar status gizi atau indeks masa tubuh maka tekanan darah akan semakin tinggi.

\section{UCAPAN TERIMA KASIH}

Ucapan terima kasih ditujukan kepada para penguji skripsi dan kepada semua pihak yang secara langsung maupun tidak langsung telah memberikan ide dan gagasan pada penulis.

\section{DAFTAR PUSTAKA}

1. Hendrayati, Salmiah, Rauf S. Pengetahuan gizi, pola makan, dan status gizi siswa SMP Negeri 4 Tompobulu Kabupaten Bantaeng. Media Gizi Pangan. 2010;9:33-4.

2. Badan Penelitian dan Pengembangan Kesehatan Kementerian Kesehatan RI. Riskesdas $2010 . \quad$ Available from: http://www.riskesdas.litbang.depkes. go.id/download/TabelRiskesdas2010.pdf.

3. Wulandari T, Zulkaida A. Self regulated behavior pada remaja putrid yang mengalami obesitas. Proceeding PESAT. 2007;2:B51.

4. Novianingsih E, Kartini A. Hubungan antara beberapa indikator status gizi dengan tekanan darah pada remaja. Journal of Nutrition College 2012;1:220-6.

5. Saing J. Hipertensi pada remaja. Sari Pediatri. 2005; 6:159.

6. Sembiring AAT. Prevalensi anak obesitas di Sekolah Dasar di Kota Medan. USU ejurnals. 2010;40. Available from: http://repository.usu.as.id./handle/1234567 89/18779.

7. Hidayati SN, Hadi H, Lestariana W. Hubungan asupan zat gizi dan indeks massa tubuh dengan hiperlipidemia pada murid SMP yang obesitas di Yogyakarta. Sari Pediatri. 2006;8:26.

8. Umboh A, Kasie J, Edwin J. Hubungan antara resistensi insulin dan tekanan darah pada anak obes. Sari Pediatri. 2007;8:290.

9. Verma M, Chhatwal J, George SM. Obesity and Hypertension in Children. Indian Pediatrics 1994;31:1065-69.

10. Sorof J, Daniels S. Obesity Hypertension in Children a problem of Epidemic Proportions. Hypertension 2002;40:441-7. 
391 Jurnal e-Biomedik (eBM), Volume 1, Nomor 1, Maret 2013, hlm. 387-390 